\title{
SURVEY OF LEGAL ISSUES: CANADIAN OFFSHORE OIL AND GAS DEVELOPMENTS
}

\author{
DOUGLAS BLACK and F.V.W. PENICK*
}

In this paper the authors review the principal legal issues related to the development of oil and gas resources off the Canadian Eastcoast. Included are a review of the applicable law's, a discussion of licenses and regulatory powers. local benefits policies. employment issues. admiralty issues, taxation issues and environmental issues.

\section{TABLE OF CONTENTS}

I. INTRODUCTION ...................... 179

II. COASTAL STATES' RIGHTS IN THE CONTINENTAL SHELF $\ldots \ldots \ldots \ldots \ldots \ldots \ldots \ldots \ldots$

III. THE LEGAL REGIME FOR OFFSHORE

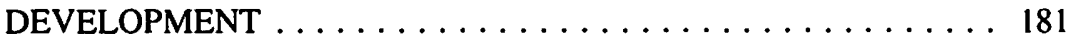

A. THE HIBERNIA REFERENCE $\ldots \ldots \ldots \ldots \ldots \ldots \ldots 181$

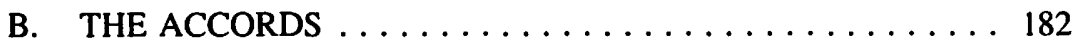

C. APPLICATION OF LAWS IN THE OFFSHORE . . . . . 183

IV. THE ACCORD IMPLEMENTATION ACTS AND

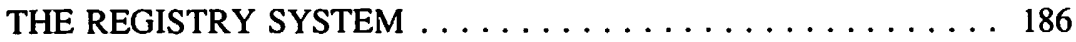

A. DISPOSITION OF RIGHTS $\ldots \ldots \ldots \ldots \ldots \ldots \ldots \ldots 187$

B. TRANSFER OF RIGHTS $\ldots \ldots \ldots \ldots \ldots \ldots \ldots \ldots 188$

C. REGISTRY OF RIGHTS AND SECURITY INTERESTS . . . . . . . . . . . . . . . . . . 189

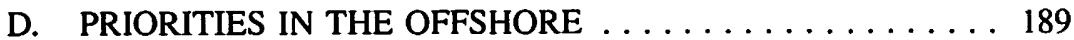

V. LOCAL BENEFITS POLICIES $\ldots \ldots \ldots \ldots \ldots \ldots \ldots \ldots \ldots$

VI. PERSONNEL ISSUES $\ldots \ldots \ldots \ldots \ldots \ldots \ldots \ldots \ldots \ldots \ldots$

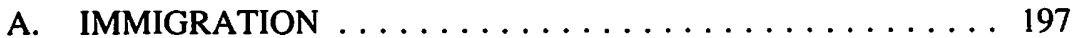

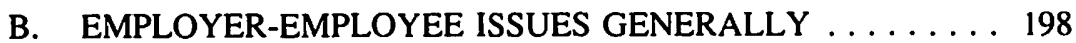

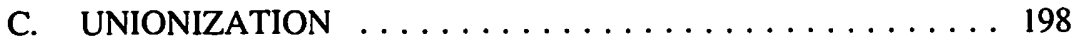

D. OCCUPATIONAL HEALTH AND SAFETY $\ldots \ldots \ldots \ldots 201$

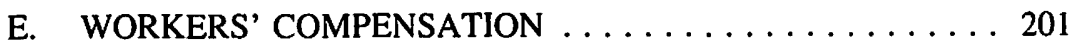

VII. SOME MARITIME LAW ISSUES $\ldots \ldots \ldots \ldots \ldots \ldots \ldots \ldots 203$

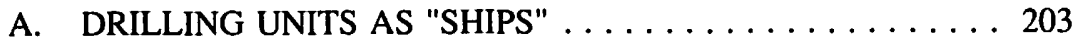

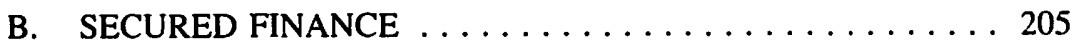

C. THE STATUS OF DRILLING CONTRACTS $\ldots \ldots \ldots \ldots 206$

D. MARITIME TORTS AND LIMITATION OF LIABILITY . . . . . . . . . . . . . . . . . . . . 207

VIII. THE FISCAL REGIME $\ldots \ldots \ldots \ldots \ldots \ldots \ldots \ldots \ldots \ldots 208$

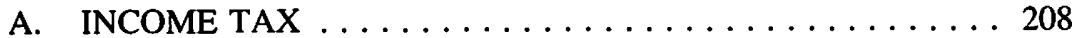

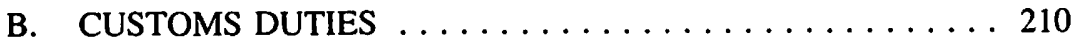

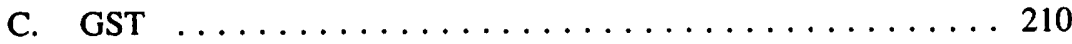

Halley, Hunt, St. John's, Newfoundland and McInnes Cooper \& Robertson, Halifax, Nova Scotia respectively. 
D. PROVINCIAL SALES TAX $\ldots \ldots \ldots \ldots \ldots \ldots \ldots 212$

IX. ENVIRONMENTAL REGULATION $\ldots \ldots \ldots \ldots \ldots \ldots \ldots 213$

A. EXPLORATION .................. 213

B. SECTION 67(1) OF THE CANADA ENVIRONMENTAL PROTECTION ACT (CEPA) . . . . . . . . . . . 214

C. SECTIONS 35 AND 36 OF THE FISHERIES ACT ...... 214

D. TRANSPORTATION OF DANGEROUS GOODS ACT $\ldots \ldots 214$

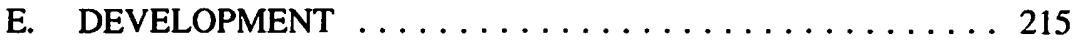

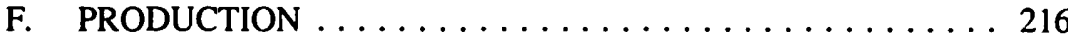

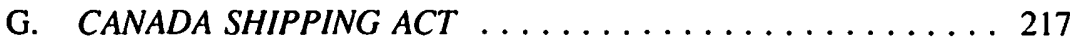

H. ACCORD IMPLEMENTATION ACTS ........... 217

X. CONCLUSION ...................... 217

\section{INTRODUCTION}

The announcements in 1990 that hydrocarbon developments at Hibernia, offshore Newfoundland and Cohasset-Panuke, offshore Nova Scotia will proceed signalled a quantum leap in activity off the east coast of Canada. Unlike the Petroleum Incentive Program driven exploration programs of the early 1980s, development and production activity of the 1990s is largely motivated by market forces. From discoveries already made and delineated, a full generation of work is anticipated for the offshore oil and gas industry and its legal advisors.

The legal regimes under which the oil and gas industry now operates off the east coast bear little resemblance to that imposed by the National Energy Program legislation of the Trudeau era. Gone are progressive incremental royalties, mandatory Crown share, rigorous Canadian ownership requirements and broad ministerial discretion, together with unsigned exploration agreements, legislative lacunae and ghost registries - replaced by a system more palatable to participants in offshore development.

Gone also are the constitutional uncertainties over offshore hydrocarbon ownership and the hostile inter-governmental confrontations which dominated and plagued the period from 1979 to 1985 .

Now there are new federal-provincial offshore resource agreements implemented through mirror legislation, not only enacted but proclaimed in force. The ambit of federal laws has been extended to the continental shelf and the mechanism exists to similarly extend provincial laws.

The legislative focus has shifted from getting the political upper hand to regulating a responsible industry in an even-handed manner.

This paper discusses the current legal issues which face rights holders and contractors engaged in hydrocarbon exploration, development and production of shore Newfoundland and Nova Scotia, starting with a coastal state's rights in the continental shelf under international law. 


\section{COASTAL STATES' RIGHTS IN THE CONTINENTAL SHELF}

International law recognizes that a coastal state may extend its physical boundaries seaward for up to twelve miles,' and Canada has done so. ${ }^{2}$ The twelve mile territorial sea is part of Canada but, generally, not part of a province.

Beyond the twelve mile territorial sea, a coastal state's rights are significantly restricted from the complete and exclusive sovereignty which a state enjoys within its boundaries. Article 77 of the United Nations Convention on the Law of the Sea III $^{3}$ recognizes a coastal state's rights to the natural resources of the continental shelf:

\section{Article 77}

Rights of the coastal State over the continental shelf

1. The coastal State exercises over the continental shelf sovereign rights for the purpose of exploring it and exploiting its natural resources.

2. The rights referred to in paragraph 1 are exclusive in the sense that if the coastal State does not explore the continental shelf or exploit its natural resources, no one may undertake these activities without the express consent of the coastal State.

3. The rights of the coastal State over the continental shelf do not depend on occupation, effective or notional, or on any express proclamation.

4. The natural resources referred to in this Part consist of the mineral and other non-living resources of the sea-bed and subsoil together with living organisms belonging to the sedentary species, that is to say, organisms, which, at the harvestable stage, either are immobile on or under the sea-bed or are unable to move except in constant physical contact with the sea-bed or the subsoil.

The continental shelf extends to the edge of the natural prolongation of a coastal state's dry land mass or 200 miles, whichever is greater. ${ }^{4}$

The legal characterization of the sovereign rights to explore and exploit the natural resources of the continental shelf beyond the territorial sea has not been settled ${ }^{5}$ and Canada appears to have adopted the conservative position, that it does not hold any real property rights, as opposed to personal property rights, in the natural resources of the continental shelf.

United Nations Convention on the Law of the Sca. Done at Montego Bay, Jamaica, December 6, 1982, Article 3. U.N. DOC. A/CONF. 62/122 (1982), 21 lnt. Leg. Mat. 1261.

2. Territorial Sea and Fishing Zones Act, R.S.C. 1970, c.T-7.

3. Supra, note 1 .

4. Ihid. Article 76.

s. See, for instance, F.V.W. Penick, "The Legal Character of the Right to Explore and Exploit the National Resources of the Continental Shelf" (1985) 22 San Diego L. Rev. 765. 
States other than coastal states are entitled to certain non-exclusive rights on the continental shelf such as navigation, cable laying and fishing rights. A coastal state's laws which apply to the offshore must therefore be sensitive to and not interfere with the rights of other nations. The legislation implementing the federal-provincial offshore accords and the legislation extending federal and provincial laws into the continental shelf have been carefully drafted to observe these international rights.

\section{THE LEGAL REGIME FOR OFFSHORE DEVELOPMENT}

\section{A. THE HIBERNIA REFERENCE}

Constitutional and political jurisdiction over the offshore has been a topic of intense dispute between the coastal provinces and the federal government since the mid-1960s. It was not until 1984, however, that the principal issues in the dispute were determined by the Supreme Court of Canada in Reference Re: The Seabed and Subsoil of the Continental Shelf Offshore Newfoundland (the Reference). The question put to the Court in the Reference was whether the government of Canada or the government of Newfoundland had the legislative and limited proprietary rights to explore and exploit the minerals in the small portion of the continental shelf off the coast of Newfoundland and Labrador covering the Hibernia field. The Court's reasons extend to the whole of the continental shelf.

It should be noted that in the Reference the Court was not asked to determine whether a coastal state had the right to extend its laws to the continental shelf. The Court recognized the limited right of a coastal state under international law to extend its laws to the exploration and exploitation of the mineral reserves situated under the continental shelf. The question before the court was whether this right belonged to the government of Canada or the government of Newfoundland.

The Court held that such a right to the continental shelf belonged exclusively to the government of Canada. The Court noted that Newfoundland may once have been in a position to lay claim to this extra-territorial right, but if this was ever the case, the province surrendered this right when it entered Confederation.

The Court ruled that $\mathbf{s . 9 2}$ of the Constitution Act, 1867 restricted provincial jurisdiction to those areas located within the province. Since the continental shelf lay outside the boundaries of the province, legislative authority must rest with the federal government under its residual authority contained in the peace, order and good government provision of the Constitution.

It should be remembered that the right, which the Court determined lay with the federal government, was not the right of full sovereignty over the continental shelf. Rather, the right which belonged to the federal government was merely the right to govern the exploration and exploitation of the mineral reserves located on the shelf. Though these 
rights were an extension of a coastal state's sovereignty, "... it is an extension in the form of something less than full sovereignty ... the continental shelf is not part of a coastal state's territory ... [and therefore] the coastal state cannot 'own' the continental shelf as it can 'own' its land territory."7 For this reason, federal laws do not automatically apply to the continental shelf. In order for such laws to apply, the federal government must pass legislation explicitly extending the application of its laws beyond its boundaries to the continental shelf.

\section{B. THE ACCORDS}

While the decision in the Reference answered the legal question surrounding the offshore dispute, political negotiations continued, assisted by a change in control in the federal government. On February 11, 1985, a compromise was reached when the government of Newfoundland and the government of Canada signed the CanadaNewfoundland Accord on Joint Management of Offshore Oil and Gas Resources off Newfoundland and Labrador (the Atlantic Accord). While the Atlantic Accord would not change the constitutional fact that the jurisdiction over the continental shelf rested with the federal government, it recognized the political fact that the province ought to participate in the governance of the area.

Meanwhile, in fact before the Reference had been decided, the government of Nova Scotia had entered into an offshore management and revenue sharing agreement with the Trudeau government, which was less favourable to Nova Scotia than the Atlantic Accord was to Newfoundland. This agreement did, however, include a "most favoured nation" provision and after Newfoundland's Atlantic Accord was concluded, Nova Scotia entered into a nearly identical agreement on August 26, 1986.

The two accords were made law by two sets of mirror legislation:

(a) The Canada-Newfoundland Atlantic Accord Implementation Act, S.C. 1987, c.3, proclaimed in force on April 4, 1987 except for ss. 102-118 which were proclaimed in force on May 20, 1988 and ss. 207-208 which have not been proclaimed; the CanadaNewfoundland Atlantic Accord Implementation (Newfoundland) Act, S.N., 1986, c.37, proclaimed in force on April 4, 1987. In this paper we refer to the legislation implementing the Atlantic Accord as the Newfoundland Accord Act.

(b) The Canada-Nova Scotia Offshore Petroleum Resources Accord Implementation Act, S.C. 1988, c.28, proclaimed in force on December 22, 1989, except for ss.105-121 which were proclaimed in force on October 1, 1990; the Canada-Nova Scotia Offshore Petroleum Resources Accord Implementation (Nova Scotia) Act, S.N.S. 1987, c.3, proclaimed in force on January 5, 1990 except for ss. 104-120 which were proclaimed in force on October 1, 1990. In this paper we refer to the legislation implementing the Nova Scotia Accord as the Nova Scotia Accord Act and we refer to both as the Accord 
Implementation Acts. Section references in this paper refer to the federal legislation in each of the Accord Implementation Acts.

\section{APPLICATION OF LAWS IN THE OFFSHORE}

Laws of a province cannot be extended beyond the boundaries of the province, because the provincial authority to make laws is restricted to laws within the province. Laws of Canada, unless they use specific language extending their territorial application, do not apply on the continental shelf. Such extension requires the express reference to Parliament's exercise of its extra-territorial sovereignty. ${ }^{8}$ Parliament may do this in a number of ways:

(a) Parliament may provide in a particular act that that act applies offshore. An early (and unsurprising) example is the Income $\operatorname{Tax} A c t ;{ }^{9}$ section 255 provides that for the purposes of the Income Tax Act, Canada includes, and has always included, the seabed and subsoil of submarine areas adjacent to Canada in respect of which rights to explore for and take minerals or petroleum are granted;

(b) Parliament may provide in an act that it and other named acts apply offshore. Those acts extending certain other acts into the Newfoundland and Nova Scotia offshore areas are as follows:

the Newfoundland Accord Act which makes applicable,

s. 97: Petroleum and Natural Gas Act

s. 101: Part VII of the Canada Petroleum Resources Act

s. 152: Boiler, Pressure Vessel and Compressed Gas Act

Elevators Act

Labour Standards Act

Occupational Health and Safety Act

Radiation Health and Safety Act

Workers Compensation Act

The Labour Relations Act

s. 206: Retails Sales Act

Gasoline Tax Act

Tobacco Tax Act

Insurance Premiums Tax Act

Newfoundland Income Tax Act

Newfoundland Insurance Company's Tax Act;

See, for instance, lan Townsend-Gault, Petroleum Operations on the Canadian Continental Margin, the Canadian Institute of Resources Law, February 1983; also the Regulatory Impact Analysis Statement annexed to the Hihernia Development Project Offshore Application Regulations. SOR/90774.

9. $\quad$ S.C. $1970-71-72$, c. 63.

11. Petroleum and Natural Gas Act, R.S.N. 1970, c.294; Canada Petroleum Resources Act, R.S.C. 1985 (2nd supp.), c.36; The Boiler, Pressure Vessel and Compressed Gas Act, S.N. 1981, c.12; The Elevators Act, R.S.N. 1970, c.107; The Labour Standards Act, S.N. 1977, c.52; The Occupational Health and Safery Act, S.N. 1978, c.23; The Radiation Health and Safety Act, S.N. 1977, c.90; The 
the Hibernia Development Project Act, ${ }^{11}$

s.7: prescribed federal laws in relation to banking, bills of exchange, promissory notes, etc. The following were prescribed in SOR/90-774,

Parts I and V and Schedules VI, VII, VIII, and IX of the Bank Act

Bankruptcy Act

Bills of Exchange Act

Interest Act; ${ }^{12}$

s.8: provincial laws in relation to the perfection of security interests, including,

Assignment of Book Debts Act

Bills of Sale Act

Conditional Sales Act

Conveyancing Act

Registration of Deeds Act; ${ }^{13}$

(iii) the Nova Scotia Accord Act which makes applicable,

s.99: the Offshore Petroleum Royalty Act

s.103: Part VII of the Canada Petroleum Resources Act

s.157: Labour Standards Code

Occupational Health and Safety Act

Trade Union Act

Workers' Compensation Act

s.212: Health Services Tax Act

Gasoline and Diesel Oil Tax Act

s.213: Nova Scotia Insurance Premium Tax Act

s.216: Nova Scotia Income Tax Act ${ }^{14}$ and

(c) Finally, Parliament may enact broad legislation extending all federal and even provincial laws into the of fshore. The Canadian Laws Offshore Application Act, S.C. 1990, c. 44 is such an act.

Workers' Compensation Act. 1983, S.N. 1983, c.48; The Labour Relations Act, 1977, c.64; The Retails Sales Act, 1978, S.N. 1978, c.36; The Gasoline Tax Act, 1978, S.N. 1978, c.39; The Tobacco Tax Act. 1978, S.N. 1978, c.38; The Insurance Premiums Tax Act. 1978, S.N. 1978, c.40; The Income Tax Act, R.S.N. 1970, c.163; and The Insurance Company's Tax Act, R.S.N. 1970, c.177.

11. S.C. 1990, c.41.

12. Bank Act, R.S.C. 1985, c.B-1; Bankruptcy Act, R.S.C. 1985, c.B-3; Bills of Exchange Act, R.S.C. 1985, c.B-4; and Interest Ait, R.S.C. 1985, c.I-15.

13. The Assignment of Book Debts Act, R.S.N. 1970. c.15; The Bills of Sale Act, R.S.N., 1970, c.21; The Conditional Sales Act, R.S.N. 1970, c.56; The Conveyancing Act, R.S.N. 1970, c.63; and The Registration of Deeds Ac\%, R.S.N. 1970, c.328.

14. Offshore Petroleum Royalty Act, S.N.S. 1987, c.9; Canada Petroleum Resources Act, R.S.C. 198.5, c.36 (2nd supp.): Lahour Standards Code, R.S.N.S. 1989, c.246; Occupational Health and Safety Act. R.S.N.S. 1989, c.320; Trade Union Act, R.S.N.S. 1989, c.475; Workers' Compensation Act, R.S.N.S. 1989. c.508; Health Services Tax Act. R.S.N.S. 1989, c.198; Gasoline and Diesel Oil Tax Act, R.S.N.S. 1989, c.183; Insurance Premiums Tax Act, R.S.N.S. 1989, c.232; and Income Tax Act, R.S.N.S. 1989 , c.217. 
The Canadian Laws Offshore Application Act recognizes that the continental shelf extends beyond the territorial sea and then sets out to extend federal laws into the area. According to provisions of s.5(1)(a), federal laws apply:

...on or under any marine installation or structure from the time it is attached or anchored to the Continental Shelf in connection with the exploration of that Shelf or the exploitation of its mineral or other non-living resources until the marine installation or structure is removed from the waters above the Continental Shelf.

In this Act, "marine installation" includes any ship, offshore drilling unit, production platform, seabed installation, pumping station and living accommodation. ${ }^{15}$ This section only extends federal laws to marine installations once they have become attached to the continental shelf due to Parliament's sensitivity to the fact that it has no jurisdiction to regulate any activities on the continental shelf which are not related to the exploration or exploitation of mineral reserves in the shelf. This is further recognized in s.6(c) of this Act which states that, for purposes of s.5, federal law should be applied:

...in a manner that is consistent with the rights and freedoms of other states under international law, in particular, with the rights and freedoms of other states in relation to navigation and overflight.

As a result of $s .5$, it will not be terribly important to the offshore oil and gas industry to examine particular federal statutes to see if they extend themselves by their own terms to the offshore.

This Act also addresses the issue of the application of provincial laws to the offshore area, but the operative provision (s.7) has not yet been proclaimed in force. By virtue of s.2(1) of this Act, "offshore area," with respect to a province, is defined as:

Any area of the sea that is not within a province, that is on the landward side of the outer limits of the continental shelf and that is nearer to the coast of that province than to the coast of any other province.

Having so defined the offshore area, s.7(1) of this Act then states that, subject to the section, and any other act of parliament:

(a) provincial laws apply in that part of the offshorc area adjacent to a province that forms part of the internal waters or territorial sea: and

(b) provincial laws apply to the same extent as federal laws apply pursuant to section 5 in that part of the offshore area adjacent to a province that is situated on the seaward side of the internal waters and territorial sea.

As can be seen by 5.7 of this Act, the laws of all coastal provinces (subject to the existence of federal laws) will apply after proclamation of s.7 to two areas where such laws did not previously apply. The first area includes the territorial sea of Canada which, 
as previously noted, is under the sole jurisdiction of the federal government. The second area involves marine installations to which federal laws apply pursuant to s.5 of this Act.

However, it should be pointed out that $\$ .7$ makes it clear that provincial laws will only apply to these areas insofar as there is no existing federal legislation. Therefore, while both provincial and federal laws will apply to the offshore area, federal laws will have paramountcy over provincial laws.

Finally, it should be noted that the Canadian Laws Offshore Application Act also makes amendments to the Coastal Fisheries Protection Act, the Criminal Code, the Immigration Act, the Canada Shipping Act and the Territorial Sea Fishing Zones Act. All such amendments are designed to have the respective acts recognize the fact that federal laws now have certain application to the continental shelf.

By implementing this particular regime in the offshore, the federal government has accomplished three important goals. First, the regime extends the application of federal laws to marine installations situated on the continental shelf; second, the regime retains within the federal government the power to control the legislation which will be applicable to the area; and third, it will allow provincial laws to fill any legislative voids not already occupied by federal law.

The legal regime presently in place within the offshore area is a combination of international law, Canadian constitutional law, and political compromise. As a result, the regime is complex, and as of this time, untested. With this background we turn to consider the present administrative regime and the system for registration of licenses and security interests.

\section{THE ACCORD IMPLEMENTATION ACTS} AND THE REGISTRY SYSTEM

The subject of the Accord Implementation Acts is the joint federal/provincial management of exploration and development activities located on the continental shelf. To accomplish this task, each act establishes a joint regulatory offshore petroleum board (the "Board"). The Newfoundland Board is comprised of seven members: three appointed by the federal government, three by the Newfoundland government and a chair to be selected by mutual consent. The Nova Scotia Board has five members, similarly balanced. Each Board is given a broad range of powers that allows it to oversee all aspects of exploration and development in the offshore area. In particular, each Board has the authority to make final decisions on the administration of regulations respecting good oil field practice, the exercise of emergency powers respecting safety, spills and conservation, and decisions on compliance issues. In addition, the Board has the power to make initial decisions on "fundamental" matters and will oversee the implementation of the local benefits policies.

While many of the decisions made by the Board will be final, some of its decisions are subject to government approval. Such is the case when the Board makes what is known 
as a "fundamental decision." ${ }^{16}$ Under the terms of the Accord Implementation Acts, there are three sets of Board decisions which fall within the category of "fundamental decision":

(a) Decisions calling for proposals and issuing rights;

(b) Decisions regarding the exercise of extraordinary powers, such as directing an interest holder to drill a well, requiring the commencement, continuation, increase or suspension of production, cancelling the rights of an interest holder and requiring an interest holder to introduce specific measures to prevent waste; and

(c) Decisions regarding the approval of a development plan with respect to the choice of the production system, the planned level of recovery of the resource in place, the pace and timing of the implementation of the project, and any fundamental revision to any of the foregoing.

Fundamental decisions made by the Board are not final until they receive the approval of, depending on the nature of the decision, either the federal Minister of Energy, Mines and Resources or the provincial energy minister.

The Accord Implementation Acts also enunciate the local benefits preference policy, establish a development fund to finance infra-structural development, provide for public review of prospective developments and allow for administrative review of plans for the use of goods and services and for employment in connection with exploration and development work programs.

The Accord Implementation Acts are nearly identical and the sections on the issuance and registration of oil and gas rights and the technical, safety and environmental aspects of hydrocarbon development activities closely follow the Canada Petroleum Resources Act. ${ }^{17}$ Highlights of the rights management system and legal issues arising therefrom are as follows.

\section{A. DISPOSITION OF RIGHTS}

There are two basic stages of rights - exploration licences and production licences:

(a) following calls for bids, exploration licences are granted by the Board based on criteria set out in the Board's call. ${ }^{18}$ An exploration licence describes the area within which the holder has the exclusive rights to drill for oil and gas, to develop that area for production and to obtain a production licence. ${ }^{19}$ There is a mechanism by which a holder can convert all or part of an exploration license

18. Newfoundland Accord Act, ss. 58-59; Nova Scotia Accord Act, ss. 61-62.

14. Newfoundland Accord Act, s. 65; Nova Scotia Accord Act, s. 68. 
into the third kind of licence, a significant discovery licence, which differs from an exploration licence only in that there is no term and the Board can order further drilling ${ }^{20}$ and

(b) the holder may ask the Board to declare that a discovery has been demonstrated to contain reserves justifying the investment of capital and effort to bring the discovery to production $;^{21}$ if the Board makes such a declaration of commercial discovery, then the holder may apply for a production licence for the area where the commercial discovery extends. ${ }^{22}$ A production licence gives the holder the exclusive right to produce petroleum from the production licence area and title to the petroleum so produced. ${ }^{23}$ Before a production licence will be issued to a holder, the federal Minister of Energy, Mines and Resources must be satisfied that the holder has a Canadian ownership rate of at least $50 \%{ }^{24}$

The scheme of disposition encourages the matching of the area under licence to the geological structures explored or developed - on the vertical as well as on the horizontal plane. Although there has been some uncertainty over the Board's power to grant stratigraphically divided rights in certain grandfathered circumstances, ${ }^{25}$ it appears from the award of at least one right that this issue is no longer in doubt. ${ }^{26}$ The Board is prohibited from unilaterally dividing up the column in which a right vested under previous legislation operates, ${ }^{27}$ but if the holder of such a right requests, the Board does have the power to grant a right covering a stratigraphically identified formation.

Newfoundland Accord Act, ss. 71-76; Nova Scotia Accord Act, ss. 74-79. Two cases have arisen with respect to the extent of a significant discovery area: Mobil Oil Canada, Lid. et al v. Minister of Energy, Mines and Resources (Canada), an unreported decision of Reed J., F.C.T.D. T-460-90, March 15, 1990, in which the applicants sought unsuccessfully to overturn a decision of the Minister to make a declaration of significant discovery extending to eleven sections surrounding the applicant's Nautilus C-92 well; and Mobil Oil Canada Lid., et al v. Canada-Newfoundland Offshore Petroleum Board, an unreported decision of Wells, J. S.C.N.T.D. No. St. J. 3151, October 25, 1990 , (presently under appeal) in which the applicants sought successfully to require the offshore board to consider their application for a declaration of significant discovery over certain sections adjacent to the Nautilus C-92 significant discovery area.

Newfoundland Accord Act, s. 78; Nova Scotia Accord Act, s.74.

Newfoundland Accord Act, s. 81: Nova Scotia Accord Act, s. 84.

Newfoumdland Accord Act, s. 80; Nova Scotia Accord Act, s. 83.

Newfoundland Accord Act, s. 89: Nova Scotia Accord Act, s. 91.

Newfoundland Accord Act, s. 57(3)-(4); Nova Scotia Accord Act, s. 60(3)-(4).

Production License 2901 issued by the Canada-Nova Scotia Offshore Petroleum Board on April 1, 1991 to Lasmo Nova Scotia Limited and Nova Scotia Resources (Ventures) Limited descends only to a certain depth.

Newfoundland Accord Act, s. 57(4): Nova Scotia Accord Act, s. 60(4). 


\section{B. TRANSFER OF RIGHTS}

Exploration licences, significant discovery licences or shares therein, may be transferred without the approval of the Board or any minister, ${ }^{28}$ but transfer of production licences or shares therein must be approved for Canadian ownership by the federal Minister of Energy, Mines and Resources. ${ }^{29}$ This represents a significant change from previous legislation in which no transfer of any kind was valid until approved by the federal Minister. ${ }^{30}$

\section{REGISTRY OF RIGHTS AND SECURITY INTERESTS}

Each Board maintains a public register of "interests" and "instruments,".31 and both are defined terms. "Interests" are exploration licences, significant discovery licences and production licences. ${ }^{32}$ "Instruments" are transfers of licences, security notices and assignments, postponements and discharges of security notices. ${ }^{3.3}$

No document other than an interest or an instrument may be registered ${ }^{34}$ and registration is deemed to constitute actual notice to all persons. ${ }^{35}$

\section{PRIORITIES IN THE OFFSHORE}

A registered instrument takes priority over:

(a) all subsequently registered instruments;

(b) all registerable but unregistered instruments; and

(c) all unregisterable rights acquired after the instrument was registered. ${ }^{36}$

The only statutory exception to these priority rules is that an unregistered operator's lien, arising under a joint operating or similar agreement, for advances made by the operator in respect of a non-operator's portion of agreed expenditures has priority over all other rights, even if the lien arises after an interest or an instrument has been registered. ${ }^{37}$

These clearly stated priority rules will be most helpful to lawyers giving opinions on title to offshore exploration, significant discovery and production licences. The chief

Newfoumdland Accord Act, s. 103; Nova Scotia Accord Act, s. 106. Newfoumdland Accord Act, s. 104; Nova Scotia Accord Act, s. 107.

Canada Oil and Gas Act, S.C. 1980-81-82, c.81, s.52(3), by which the Federal Minister of Energy. Mines and Resources could reject any proposal transfer on any grounds he or she considered to be in the public's interest.

Newfoumdland Accord Act, s. 105; Nova Scotia Accord Act, s. 108.

Newfoumdland Accord Act, s. 47; Nova Scotia Accord Act, s. 49.

Newfoumdland Accord Act, s. 102(1); Nova Scotia Accord Act, s. 105(1).

Newfoundland Accord Act, s. 106(1); Nova Scotia Accord Act, s. 109(1).

Newfoumalland Accord Act, s. III; Nova Scotia Accord Act, s. 114.

Newfoundland Acrord Act, s. 112(1); Nova Scotia Accord Act, s. 115(1).

Newfoundland Accord Act, s. 112(5); Nova Scotia Accord Act, s. 115(5). 
question left unanswered by these rules will be the ranking of rights, liens and trusts arising outside the scope of the accord implementation legislation. The Accord Implementation Acts are silent as to any special priorities between registered instruments and unregisterable rights, liens or trusts acquired before the instrument was registered.

A summary of the liens and other rights usually examined in the course of a commercial transaction or financing, and their effect on exploration, significant discovery and production licences is as follows:

(a) In both offshore areas

s. 177 Bank Act security - Security under s.177 of the Bank Act ${ }^{38}$ is expressly referred to in the definition of "security interest" in the Accord Implementation Acts. ${ }^{39}$ Therefore, in addition to Bank Act registration, a security notice of the security must be registered in the Accord Implementation Act registry and its priority is settled by the date of such registration;

(b) In the Nova Scotia offshore area

(i) Mortgage of a licence - The priority of a mortgage or an assignment of an exploration, significant discovery or production licence, if given to secure the repayment of money borrowed or advanced, will be protected by registering a security notice in prescribed form under the Accord Implementation registry. Since provincial "security" legislation does not apply at present in the Nova Scotia offshore (and will not until s. 7 of the Canadian Laws Offshore Application Act is proclaimed in force), there are, at present, no other registration requirements. Accordingly it is not necessary to determine whether a licence is a real property interest and the provisions of the Registry Act ${ }^{40}$ must be followed or whether the charge is given in a debenture and the provisions of the Corporations Securities Registration Act ${ }^{41}$ must be followed.

A collateral mortgage or assignment of a licence given not to secure the repayment of money but given for instance to secure a contingent liability under a guarantee is not a "security interest" under the Accord Implementation Acts and a security notice may not be registered. Such collateral security constitutes, therefore, an unregisterable right and its priority is determined by the date of its execution and delivery. 
Health Services Tax Act lien - The Health Services Tax Act ${ }^{42}$ applies in the offshore area ${ }^{43}$ by virtue of 5.212 of the Nova Scotia Accord Act. The Health Services tax is a sales tax on tangible personal property. Sellers are responsible for collecting the sales tax and s.25 creates a lien on the entire assets of the estate of a seller for any unremitted sales tax. The lien is "deemed to be a mortgage or a secured debenture and, subject to the Labour Standards Code, is payable in priority to all other liens, charges or mortgages in respect of those assets."

The sales tax lien is not an "instrument" and cannot be registered in the registry of interests and instruments administered by the Offshore Board. Accordingly, by s.115 of the Nova Scotia Accord Act it will take priority only over instruments registered after the sales tax lien arises. This provision is in obvious conflict with 5.25 of the Health Services Tax Act which purports to give the sales tax lien priority over every prior lien or charge except for the Labour Standards Code lien. The s.115 priority regime will prevail over the deemed supremacy of the sales tax lien because the application of the Health Services Tax offshore is made expressly subject to the Nova Scotia Accord Act. ${ }^{44}$

(iii) Workers' Compensation lien - The Workers' Compensation Act ${ }^{45}$ applies by virtue of s. 157 of the Nova Scotia Accord Act on ships other than supply vessels and on drilling units, production platforms, subsea installations, pumping stations, living accommodations, storage structures or loading or landing platforms used in the offshore in connection with the exploration for or production or processing of petroleum. ${ }^{46}$ Section 136 of the Workers' Compensation Act provides for the creation of a "first lien" for unpaid assessments on all the property, real, personal or mixed, used in connection with or produced by the industry of the defaulting employer.

As with the sales tax lien, the Workers' Compensation lien does not fit the description of an "instrument" and accordingly will line up chronologically with registered instruments against an exploration, significant discovery or production licence. And although the s.157 provisions in the Nova Scotia Accord Act are not as clear as s.212, it is submitted that the 5.115 priority system will prevail over the stated supremacy of a Workers' Compensation lien.

Supra, note 14.

Defined in Schedule I to the Nova Scotia Accord Act to include both the territorial sea and the continental shelf adjacent to the Nova Scotia coast.

Nova Scotia Accord Act, s.212(3).

Supra, note 14.

Nova Scotia Accord Act, s.157(1) and (2). 
(iv) Labour Standards Code - The Labour Standards Code $e^{47}$ contains a deemed prior mortgage on the assets of an employer for accruded vacation pay $^{48}$ and for amounts ordered to be paid by the Labour Standards Tribunal. ${ }^{49}$ This charge is subject to the same analysis as that for the Workers' Compensation lien and will constitute a charge on an exploration, significant discovery or production licence of a defaulting employer, ranking behind previously registered instruments, ranking ahead of subsequently registered instruments and subject to normal onshore rules vis a vis other unregisterable liens and charges.

(v) Mechanics' Lien Act - The Mechanics' Lien Act $t^{50}$ of Nova Scotia does not apply yet in the offshore area and will not, even when made applicable, apply to an exploration, significant discovery or production licence. It will, however, be available to charge ships and vessels for unpaid work on them when it does come into force on the continental shelf.

(c) In the Newfoundland offshore area:

(i) Assignment of book debts - The Assignment of Book Debts Act, as amended by the Hibernia Development Project Offshore Application Regulations $^{51}$ (the "Regulations"), will not affect any interest or instrument registered in the registry administered by the Newfoundland Offshore Board, but does apply in the Newfoundland offshore. It provides that every assignment of book debts made by any person engaged in a trade or business is void as against creditors and subsequent purchasers of the assignor, unless the assignment is in writing; accompanied by an affidavit of execution, where the assignor is not a corporation, and an affidavit of bona fides executed by the assignee; and registered in the Registry of Deeds.

However, these requirements do not apply:

- to an assignment made by a corporation and contained in a trust deed, bonds, debentures or debenture stock of the corporation;

- an assignment of debts due the date of the assignment from specified debtors;

- specific assignments of particular debts;

- an assignment included in the bona fides transfer of a business; and

- an assignment for the general benefit of creditors under the Bankruptcy Act.

Supra, note 14.

Ibid. s.36(2).

lhid. s.88.

R.S.N.S. 1989, c.277.

SOR/90-774. 
Under this Act, the first in time of registration does not necessarily take priority. Rather, where an assignor has granted more than one assignment of book debts, the first assignee to give notice to book debtors will take priority to the amounts owed by these book debtors. Actual notice of a prior assignment will also affect the priorities.

(ii) Registry of Bills of Sale, Conditional Sales and Chattel Mortgages With respect to both conveyances and mortgages of chattels, the Bills of Sale Act, as amended by the Regulations sets out the necessary registration particulars. Again, charges hereunder will not affect registered interests and instruments under the Newfoundland Accord Act. Generally, the Bills of Sale Act provides that,

a sale or mortgage that is not accompanied by an immediate delivery and an actual and continued change of possession of the chattels sold or mortgaged is, unless the sale or mortgage is evidenced by a registered bill of sale, void as against a creditor and as against a subsequent purchaser or mortgagec claiming from or under the grantor in good faith for valuable consideration without notice whose conveyance or mortgage has been registered ...52

Essentially, priority under this legislation is determined by order of registration. Where a sale or mortgage occurs without change of possession to the purchasers or mortgagee, and registration is not effected, the first mortgagee or purchaser may lose priority to a subsequent encumbrancer whose Bill of Sale is registered first.

The Regulations dispense with the usual requirement that registration be effected within thirty days of execution of the Bill of Sale. ${ }^{53}$

Registrations made under this Act will cease to be valid three years after the date of registration, and a renewal statement is required in order to preserve the effect of the Bill of Sale. Obviously, where the indebtedness secured by the registered Bill of Sale has an amortization period of greater than three years, attention should be given to the requirement for renewal statements.

Aside from the requirements of the Bills of Sale Act, where goods are sold under the condition that property in the goods is to vest in the buyer at a subsequent time upon payment of the price or where a lease of chattels contains an option to purchase, the sale or lease will fall within the definition of "conditional sale" within the meaning of the Conditional Sales Act. Where this act applies, sellers will be required 
to register conditional sales in order to preserve their title in the goods as against creditors and subsequent purchasers or mortgagees claiming under the buyer. Again, the Regulations dispense with the requirement that the conditional sale be registered within thirty days of its execution, although this Act still requires that the document be executed within ten days of delivery of the goods to the buyer.

(iii) Registration of Deeds - Both the Bills of Sale Act and the Assignment of Book Debts Act have no application to a specific or floating charge of a corporation (or of a partnership of corporations pursuant to the Regulations), which assigns book debts or mortgages or conveys chattels, and is contained in bonds, debentures or debenture stock of the corporation, or a trust deed securing these same documents. ${ }^{54}$

The Registration of Deeds Act recognizes that these other acts have no application to such documents and requires their registration in the central Registry of Deeds at St. John's. Failure to register such documents as a floating charge on the undertaking of a corporation, or a specific or floating mortgage or charge of chattels created by a corporation and contained in bonds, debentures or debenture stock, or a trust deed securing the same, results in these documents becoming void as against creditors of the corporation. Again, for purposes of the Newfoundland offshore area, the Regulations deem the term "corporation" to include a partnership of corporations.

If a holder of a production license borrows money and gives the lender a charge on the production license contained in a debenture, not only must a security notice be registered in the registry administered by the Offshore Board, but the debenture will also have to be registered pursuant to the Registration of Deeds Act.

While it is clear that such documents need not be registered anywhere other than the Registry of Deeds and the registry administered by the Offshore Board, as a practical matter, it may be advisable to register elsewhere in the interest of avoiding unnecessary litigation.

Additionally, the Registration of Deeds Act provides that all "instruments" not properly registered are void as against subsequent purchasers or mortgagees for valuable consideration who register first, as well as against trustees in bankruptcy and execution creditors who have levied. ${ }^{55}$ "Instruments" are broadly defined under this Act as conveyances, mortgages, releases or transfers of mortgages and deeds or other assurances whereby lands or tenements in the province are 
granted, conveyed, mortgaged, charged or "otherwise affected." instrument is stated, however, not to include judgments.

Clearly, dry land in the province of Newfoundland is within the scope of these registration requirements. The question which arises is whether production licenses granted in relation to the offshore area must also be registered pursuant to this legislation, as well as pursuant to the Newfoundland Accord Act. There is no clear answer to this question at the present time.

It may be argued that a production licence "otherwise affects" lands in the offshore area. Section 8(2) of Hibernia Development Project Act provides that Newfoundland's "security interest" laws will be applied "as if the offshore area formed part of the territory of the Province of Newfoundland." Further, regulation 3(1) of the Regulations specifically prevents chattels affixed to the seabed from being treated as "fixtures," as if the seabed possesses enough of a real property character to have the law of fixtures apply.

However, notwithstanding the adoption of Newfoundland law for the purposes of the offshore area in this manner, it would be difficult, in light of the limited rights Canada as a nation enjoys in the continental shelf, to suggest that such adoption deems lands in the offshore area to become lands in the province. This is undoubtedly an area which will require further clarification, although the prudent course of action clearly involves registration at the Registry of Deeds.

(iv) Statutory liens - While not dealing with registrations required to be made to protect or preserve a charge, the area of statutory liens upon real and personal property is one which affects the registration of security interests. In the province of Newfoundland, the following statutory liens exist under statutes which apply in the offshore area.

(1) Under the Workers' Compensation Act, ${ }^{57}$ the amount of any assessment is a first lien upon all property of the person to whom the assessment is charged, whether or not that property is used in or in conjunction with, or produced by or in any industry, with respect to which the employer is assessed.

(2) Under the Retail Sales Tax Act, ${ }^{58}$ an amount of tax collected and not paid to the Province is a first lien upon the assets of the estate of the person who collected the tax, and is stated to have priority over all other claims of any person.

Ibid. s.6(1)(b).

Supra, note 10, s. I10(2).

Supra, note 10, s.47. 
(3) Under the Labour Standards Act, ${ }^{59}$ a person to whom unpaid wages are due and owing by an employer has in respect of those wages, first priority in claim over the claims of all creditors of the employer, including claims of the Crown, to the extent of $\$ 2,000.00$.

The issue of the respective priorities accorded these statutory liens is a complex one and persons advancing funds upon the security of real or personal property must be aware of the potential existence of such liens. For reasons stated above ${ }^{(x)}$ persons advancing funds upon the security of a production licence will likely be protected by registration in the registry administered by the Offshore Board.

\section{LOCAL BENEFITS POLICIES}

An important part of the political resolution contained in the Atlantic and Nova Scotia Accords was the recognition that the local economies should benefit to the maximum degree (consistent with efficiency and safety) from the development of offshore areas. Such recognition resulted in the inclusion of a province-first policy in both the Accords and the Accord Implementation Acts.

According to s.134 of the Newfoundland Accord Act and s.143 of the Nova Scotia Accord Act all plans for development of the offshore must be submitted to the Board and, by virtue of $s .45$ of both Acts, the Board will not consider any development plan unless the plan includes a local benefits plan. Section $45(1)$ of the Acts defines such a plan as:

... a plan for the employment of Canadians and, in particular, members of the labour force of the Province and ... for providing manufacturers, consultants, contractors and service companies in the Province and other parts of Canada with a full and fair opportunity to participate on a competitive basis in the supply of goods and services used in any proposed work or activity...

In particular, according to s.45(3), the plan must contain the following elements:

(a) the corporation or body submitting the plan shall establish in the province an office where appropriate levels of decision-making are taking place,

(b) consistent with the Charter of Rights and Freedoms (and particularly the mobility rights protection in s.6 of the Charter), individuals resident in the province must be given first consideration for training and employment in the work programs for which the plan was submitted,

(c) expenditures shall be made for research and development to be carried out in the province and for education and training to be provided in the province, and 
(d) first consideration shall be given for services provided from within the province and to goods manufactured in the province, where those services and goods and are competitive in terms of fair market price, quality and delivery.

Only when the Board is satisfied with the contents of the local benefits plan will it approve a project.

Accordingly, contractors bidding on tenders can expect to respond to the local benefits policies in the accord implementation legislation and include such provisions in any of its subcontracts.

\section{PERSONNEL ISSUES}

\section{A. IMMIGRATION}

Generally, non-Canadians are prohibited from working in Canada unless they are granted permission pursuant to the Immigration Act." The Immigration Act does not contain a definition of Canada.

The continental shelf is not part of Canada, but as we have seen, $\mathrm{s.5}$ of the Canadian Laws Offshore Application Act provides that federal laws apply on marine installations and artificial islands on the continental shelf. Section 6 of the Canadian Laws Offshore Application Act goes on to state that for the purposes of s.5, federal laws will be applied as if the installations or islands form part of the territory of Canada.

Since the Accord Implementation Acts came into force, employers have been bound to comply with local benefits policies giving employment to residents of the adjacent province. And since the Canadian Laws Offshore Application Act came into force on February 4, 1991, employees other than Canadian citizens seeking to work in the offshore oil and gas projects on the continental shelf have required Immigration Act authorizations. The only two ways a non-citizen can take up permanent employment in Canada (now including marine installations on the continental shelf) are to obtain permanent work authorization or receive landed immigrant status. These two processes are beyond the scope of this paper.

Immigration permission for temporary work in the offshore may be obtained by qualified employees through Immigration's foreign worker policy which will require:

(i) Applications to Immigration Canada setting out the number and proposed location of the foreign workers in Canada, their occupational titles and job descriptions, the duration of their work and their proposed salary; and

(ii) Possible advertising across Canada for qualified Canadians to fill all or some of these positions. 
This is a difficult area, particularly for non-resident corporations who wish to use nonresident employees for temporary work. Such employers may be unwilling to become employers qualified to use the foreign worker policy, as this requires the establishment of an office in Canada and such an establishment may have adverse income tax consequences through the permanent establishment rules discussed below. It is possible for such employers to negotiate arrangements on a case by case basis with the immigration authorities.

The Canadian Laws Offshore Application Act has provided the legislative ability to correct one potentially burdensome administrative immigration procedure. ${ }^{62}$ If regulations are made pursuant to the new regulation making power under s.12(2) of the Immigration Act, persons being transported from a marine installation on the continental shelf to shore in Canada will no longer be treated as if they were re-entering Canada and will not have to appear before an immigration officer.

\section{B. EMPLOYER-EMPLOYEE ISSUES GENERALLY}

Prior to the passage of the Accord Implementation Acts, it had been generally accepted that federal laws applied to employment and labour concerns in the offshore. Attempts at union organizing, for example, were successfully made under the regime set out in the Canada Labour Code. The Accord Implementation Acts substantially alter the application of both employment and labour legislation.

Section 152 of the Newfoundland Accord Act and s. 157 of the Nova Scotia Accord Act make provincial "social legislation" applicable in the offshore. With the significant exception of occupational health and safety matters, as discussed below, the federal and provincial governments have selected provincial laws to regulate employment matters on marine installations or structures.

The "social legislation" of Newfoundland consists of: the Boiler, Pressure Vessel and Compressed Gas Act, the Elevators Act, the Labour Standards Act, the Occupational Health and Safety Act, the Radiation Health and Safety Act, and the Workers' Compensation Act. ${ }^{63}$ The "social legislation" of Nova Scotia consists of: the Labour Standards Code, the Occupational Health and Safety Act, the Trade Union Act, and the Workers' Compensation Act. ${ }^{64}$

\section{UNIONIZATION}

By way of background, in pre-accord days, organized labour acted within a federal scheme administered by the Canada Labour Relations Board. The Seafarers International Union (the "SIU") first made its presence felt in the East Coast offshore by representing crews aboard offshore supply vessels. In the early 1980's, with offshore exploration booming, one supply vessel operator, Balder Offshore Canada Incorporated, had ten 
supply vessels all crewed by SIU members. The SIU aggressively sought to represent other supply vessel operators as well.

The SIU had its first success in organizing employees on drilling rigs with the application to represent employees of Tap Catering and Management Limited who worked on a rig under charter to Mobil working offshore Newfoundland, the "West Venture." ${ }^{55}$ The Canada Labour Relations Board dismissed objections to its jurisdiction brought by the employer and allowed the SIU's certification application.

In July of 1985, the SIU applied for and obtained from the Canada Labour Relations Board a certification order for various classifications of employees working aboard the drilling rig Sedco $710 .^{66}$

It is generally recognized that organizing drives under the Canada Labour Code have a greater chance of succeeding than under most applicable provincial legislation. By virtue of the Accords Implementation Acts, provincial legislation now applies to most aspects of the offshore, thus narrowing the scope of the Canada Labour Relations Board.

\section{Canada Labour Code and Supply Vessels}

The definition of "marine installation" under the Accord Implementation Acts excludes supply vessel. Accordingly, the provincial social legislation does not apply on supply vessels and federal labour law does.

The Canada Labour Relations Board requires strict neutrality of employers in the face of union organizing activity ${ }^{67}$ and the unfair practices sections of the Code are more easily triggered than in the provincial counterparts - the Trade Union Act of Nova Scotia and the Labour Relations Act of Newfoundland. There is no guaranteed right of employer free speech under the federal regime. And the right to a pre-certification secret ballot vote is extremely limited. If the Canada Labour Relations Board has received an application for certification, if it has determined that the proposed unit constitutes a unit appropriate for collective bargaining, and, if the Board is satisfied that a majority of the employees in the unit wish to be represented by the trade union, then the Board shall certify. ${ }^{68}$ It may order that a vote take place if it is unable to satisfy itself as to the wishes of the employees.

Tap Catering and Management Limited and Seafarers International Union of Canada (1983), 3 C.L.R.B.R. (N.S.) 168 (Can.).

6. The bargaining unit to be represented by the S.I.U. was described in the Certification Order as:

All employees of Sedpex Inc., working on the drilling rig vessel Sedco 710, classified as roustabout, roustabout maintenance, foreman, derrickman, maintenance foreman, crane operator, thruster tender, motorman, mechanic assistant and welder.

67.

ax.

Section 94 of the Canada Labour Code R.S.C. 1985 c. L-2 prohibits "employer interference in trade union."

Section 28 of the Canada Labour Code R.S.C. 1985 c. L-2 entitled "Duty to Certify Trade Unions." 


\section{Nova Scotia Trade Union Act}

The certification process pursuant to the Nova Scotia Trade Union Act affords more flexibility to employers and places some potential obstacles in front of those seeking certification orders.

As mentioned, s. 157 of the Nova Scotia Accord Act brings the Trade Union Act into play for employees working on "marine installations or structures." This includes ships (with the exception of supply vessels), offshore drilling units, production platforms, subsea installations, pumping stations, living accommodations, storage structures, loading or landing platforms, and anything else prescribed by regulation pursuant to the legislation. So, except for supply vessel personnel, for the majority of employees working in the Nova Scotia offshore, the Trade Union Act applies.

Under the Trade Union Act, the provincial Labour Relations Board is required to order that a pre-certification secret ballot vote be carried out. Perhaps more significantly, the Act guarantees the employer's right to express its views. The Board has interpreted this right fairly broadly. In various cases, it has held that an employer may express (without threats or promises) its opinion on unionization in general, and may also:

1. urge employees to reject the union;

2. explain that although the union may make far-reaching promises, it is the employer that ultimately provides jobs and benefits;

3. report the facts on the boycott, strike and/or violence record of an applicant union;

4. inform employees of the monetary costs of union membership and remind them that they may lose individual freedom; and

5. make predictions regarding the effect of unionization on the employer, provided they are based on objective facts.

The statutory guarantee of free speech, if exercised cautiously, is a valuable tool for employers.

\section{Newfoundland Labour Relations Act}

Section 152 of the Newfoundland Accord Act is different from the corresponding section in the Nova Scotia Accord Act in that the Newfoundland Labour Relations Act applies to workers employed only on marine installations or structures which are to be permanently attached to, permanently anchored or permanently resting on the seabed.

For employees on marine installations or structures not engaged in such a permanent use (and, again, on supply vessels), the union certification provisions contained in Part I of the Canada Labour Code will continue to apply.

Getting a certification order under the Newfoundland Labour Relations Act is probably easier than doing so under Nova Scotia law but more difficult than under the Canada Labour Code. Unlike the Nova Scotia legislation, Newfoundland's does not guarantee 
employer free speech. On the other hand, the Newfoundland Labour Relations Board does not appear to share the same willingness as the Canada Labour Relations Board to find unfair labour practices.

In summary, the Canada Labour Code, probably the most pro-certification legislation, applies on supply vessels in both offshore areas and on rigs and other structures used in the exploration phase of oil and gas activity in the Newfoundland offshore. The Nova Scotia Trade Union Act, providing probably the most difficult certification climate, applies to all rigs and other marine installations used temporarily or permanently in the Nova Scotia offshore. The comparatively moderate Newfoundland Labour Relations Act applies to permanently affixed marine installations in the Newfoundland offshore.

\section{Union Avoidance}

Union avoidance is perhaps the touchiest topic arising out of industrial relations. The blunt reality is that many employers would prefer to remain union free. Employers can design effective long-term plans to achieve this goal, based upon salary and accompanying fringe benefits, working conditions, including safety considerations, communications and management leadership. Union organizers stand ready to offer dissatisfied employees union benefits through the certification process. Successful campaigns by unions and by employers will be based on the particular legislation applying in the circumstances, the attitude of the labour relations board regulating the certification process and the commitment each brings to the task.

\section{OCCUPATIONAL HEALTH AND SAFETY}

Although the occupational health and safety laws of both Newfoundland and Nova Scotia have been made applicable to marine installations in the offshore areas, ${ }^{69}$ there is really very little scope for their operation. The Accord Implementation Acts reserve to their Boards the responsibility for technical standards, efficiency, environmental compliance and safety concerns and where in conflict with the Boards' powers under the Accord Implementation Acts, the provincial legislation must yield. About all that is left are certain provincial law provisions such as the right of an employee to refuse to perform unsafe work.

\section{E. WORKERS' COMPENSATION}

Most workers employed in the Eastern Canada offshore industry are entitled to seek compensation under provincial legislation. Although the Accord Implementation Acts, as mentioned, apply provincial social legislation only to those designated works included in the definition of marine installation, the language of the provincial workers' compensation legislation appears sufficiently broad to apply to those works falling outside the definition. The Newfoundland Worker's Compensation Act affords coverage to employees working outside the province whose employer's business has a "substantial connection" with the 
province; the Nova Scotia Act will compensate an employee working outside the province where that employee's usual place of employment is inside the province. Both Acts also contain provisions affording limited compensation to non-residents who are killed or injured within provincial jurisdiction. The bottom line, then, is that employers engaged in the offshore will be assessed for the purposes of the Workers Compensation Acts and most of their employees will be eligible under the provincial schemes.

The system of guaranteed compensation to injured employees is funded solely through mandatory employer contributions. The benefit for employers is that both provincial Acts deny a worker access to the courts for the purposes of recovering damages from an employer from any injury in respect of which compensation is payable or which arises in the course of the worker's employment.

In Newfoundland, these provisions were the subject of a constitutional challenge in Reference Re Validity of Sections 32 and 34 of the Workers' Compensation Act, $1983 .^{70}$ With the exceptions of Ontario and Saskatchewan, all provinces were represented at the hearing. In holding that the Newfoundland scheme was not in violation of section 15 (1) of the Charter of Rights and Freedoms, Goodridge C.J.N. stated at page 524:

The workers' compensation scheme provides a stable system of compensation free of the uncertainties that would otherwise prevail. While there may be those who receive less under the Act than otherwise, when the structure is viewed in total, this is but a negative feature of an otherwise positive plan and does not warrant the condemnation of the legislation that makes it possible.

Two recent Nova Scotia cases have weakened the bar to action against an employer by an employee who is eligible for statutory workers' compensation. In McIntyre v. Atlantic Hardchrome Limited ${ }^{71}$ MacDonald J. held that although section 20 (formerly section 16) of the Nova Scotia Workers' Compensation Act bars claims by workers against employers for general damages arising out of injuries sustained at the work place, it does not bar actions for exemplary or punitive damages, because these damages are not compensatory. The appeal of this decision has been set down for November of 1991.

The case of Rowan Companies Inc. v. DiPersio ${ }^{72}$ involved injuries sustained by a Nova Scotia resident while working offshore in Texas. The employer had paid its assessment under the Nova Scotia scheme while the employee was working in the Nova Scotia offshore and continued payment after the employee was transferred to Texas. The employee applied for and received Nova Scotia workers' compensation benefits and then brought an action for damages in Texas against the employer. The employer sought an injunction to restrain the Texas action on the ground that section 20 of the Act barred recovery where benefits were paid. The Appeal Division refused to enjoin the Texas action on the grounds that the issue of the effect of receiving workers' compensation benefits was an issue properly determined by the Texas Court. The Workers' 
Compensation Act affected the right to sue in Nova Scotia but not the right to sue elsewhere.

If the employee in this case receives damages in the main action in the Texas court, then the employer will have received little benefit from the payment of its assessment under the Nova Scotia Workers' Compensation Act.

Employers should also be aware that recent and ongoing reviews of the workers' compensation scheme in Nova Scotia may well result in substantial increases in employer contributions to the scheme in the very near future.

\section{SOME MARITIME LAW ISSUES}

\section{A. DRILLING UNITS AS "SHIPS"}

As much of maritime law is concerned with activities involving ships and vessels, one must give preliminary consideration to the question whether mobile offshore drilling unit can be classified as a ship.

The definition of "vessel" in the Canada Shipping $A c t^{73}$ is expansive. A vessel includes:

Any ship or boat or any other description of vessel used or designed to be used in navigation.

A mobile offshore drilling unit is a vessel, whether the unit be semi-submersible or jack-up. In order for a unit to be registered as a ship pursuant to the registration provisions of the Canada Shipping $A c t,{ }^{74}$ the Registry must be satisfied that the unit is a ship within the meaning of the definition above. There are currently at least four jackup rigs registered as ships at various ports in Canada. ${ }^{75}$ In addition, the "MOLIKPAQ," an Arctic drilling caisson, is so registered. ${ }^{76}$ This unit is completely incapable of self navigation and is a steel drilling caisson upon which a drilling unit rests. The caisson has been used in the Beaufort Sea and is ballasted down onto the bottom after having been towed into position.

The practice of the Canadian ship registry system is consistent with Canadian law on the status of drilling units as vessels. The 1981 decision of the Federal Court of Appeal in R. v. Saint John Shipbuilding \& Drydock Co. Ltd. ${ }^{77}$ is instructive. In that case, the

73. R.S.C. 1985 , c. S-9, s. 2.

74. Ibid. ss. 4-22.

75. They are: 1. "EXPLORER" registered at the Port of Vancouver and owned by Aquadrill Systems Inc. of Surrey, B.C.; 2. "MISS LIBBY" registered at Port Colborne and owned by Pembina Resources Limited of Calgary. This rig has a registered tonnage of 883 tons; 3. "MR. CLIFF" registered at St. Catharine's Ontario and owned by Place Gas \& Oil Company Limited of Toronto. This is a small jack-up used for gas drilling in the lake system of Ontario; and 4. "MR. PAT" registered at Port Dover and used similarly for gas exploration in the lakes of Ontario. In the name of Gulf Canada Resources Limited with a registered tonnage of 32,267 tons.

77. (1981), 126 D.L.R. (3d) 353. 
Court considered the ship status of a floating crane used in the harbour of Saint John, New Brunswick to discharge cargo from vessels. The barge had no capability for self propulsion and was moved by a tug or by motor boat. Mr. Justice Urie referred to a series of English cases which had found floating cranes to be vessels. As to the barge in question, Mr. Justice Urie stated:

The definition of ship in the Federal Court Act is not exclusive but inclusive. It, thus, enlarges the term. She was a barge built for use on water. She was capable of being moved from place to place and was so moved from time to time ... She was capable of carrying cargo and had, in fact, done so. She was certainly capable of carrying people and obviously had to do so to enable the crew to carry out their duties. While it appears that she was not capable of navigation herself and was not self propelled, those facts do not detract from the fact that she was built to do something on water, requiring movement from place to place. Therefore, in my opinion, the'Glenbuckie' was a ship. ${ }^{78}$

Mobile offshore drilling units of any description are built for use on water and are moved from place to place. They carry cargo (drill pipe and associated equipment) and personnel including both marine and drilling crews. ${ }^{79}$

To apply these criteria to the gravity based structure being constructed for use at Hibernia, it appears that the chief difference between it and the MOLIKPAQ referred to above, is size. We understand, for instance, that the gravity based structure is designed so that after having been installed, it will be capable of being refloated, moved and redeployed. If this understanding is correct, then the structure will be capable of being moved on water from place to place. Accordingly, even though there are no plans to reuse the gravity based structure at any other site, and even though it is basically a 150,000 ton block of concrete and steel, it may well be properly characterized as a ship.

A drilling unit will remain a "ship" regardless of any changes that are made to it:

Unless it be taken apart to the extent that the separated components would merely be individual objects which were used in the construction of the ship. ${ }^{\text {xin }}$

It should be noted that if a drilling unit is a ship, then persons employed on board such ships are seamen. ${ }^{81}$

74. See also the following: Goodwin Johnson Lid. v. The Ship (Scow) "AT \& B No. 28," [1954| 2 S.C.R. 513; Falconbridge Nickel Mine's Lud. v. Chimo Shipping Lud. [1974] S.C.R. 933, [1969] 2 Ex.C.R. 261 at 298; Re Seafarers International Union of Canada v. Crosby Offshore Services Ltd. (1982), 135 D.L.R.(3d) 485 (F.C.A.) (Leave to Appeat to the Supreme Court of Canada refused.)

*o. Hamilton Harbour Conmissioners v. The A.M. German, [1973] F.C. 1254 at 1260.

*1. A seaman is defined by the Canada Shipping Act, supra, note 73 in s.2, as including persons employed or engaged in any capacity on board any ship. Regardless of their seamen's status, however, virtually all persons engaged in offshore exploration in Canada are covered by the relevant provincial Workers' Compensation schemes. The protections afforded by these schemes are dealt with elsewhere in this paper. It is worth noting, however, in the context of maritime law that in at least one American case, the Federal District Court in Houston, Texas has considered the effect of the availability of Workers' Compensation in Canada as a satisfactory remedy in a case involving 


\section{B. SECURED FINANCE}

As a ship, a drilling unit registered in Canada may be mortgaged by the use of the statutorily dictated form of mortgage. This mortgage would be placed on the Registry at the port of registry of the unit. Mortgages are granted priority from the date of their registration. ${ }^{82}$ The ship registry system functions as a method of giving notice to persons interested in, inter alia, secured mortgages registered against vessels. Ships' mortgages and the priorities accorded to them under the Canada Shipping Act do not extend to a ship's cargo. In the offshore petroleum context, this means oil stored in a shuttle or storage tanker will not be covered by a ship's mortgage, even if the oil and the ship are owned by the same person. ${ }^{8.3}$

The actual arrangements between the lender and the borrower will not be revealed by the statutory form of mortgage ${ }^{8 t}$ and are contained most usually in a document known as a Deed of Covenants. It is this document which will describe the conditions of the loan arrangement.

Deeds of Covenants will contain the terms of repayment and will usually recite a very extensive list of obligations to be carried out by the borrower, failing which the loan can be called. Because the unit is a ship, the mortgage may be subject to claims arising against the unit which will take priority regardless of when the mortgage was registered. ${ }^{85}$ Such classes of claims are known as maritime liens and do not require any form of registration. ${ }^{86}$ They simply exist upon the occurrence of an event giving rise to such a claim.

Ships registered in Canada must be owned by a Canadian or Commonwealth body corporate. ${ }^{87}$ It is not possible to register a ship in the name of a partnership. It is not

an application to send the case back to Canada on the basis of forum non-conveniens. The case is Re "ARCTIC EXPLORER" (1984), A.M.C. 2413. See also Michael F. Harrington, "Conflict of Laws and Personal Injury in the Eastern Canadian Offshore: The Aftermath of the ARCTIC EXPLORER and OCEAN RANGER Sinkings," in Sharpe and Spicer, New Directions in Maritime Law' 1984 (Toronto/London: Carswell/Stephens, 1985).

82. Supra, note 73, s.49.

83. Constant, and Benjamin. The Law Relating to the Mortgage of Ships (Sweet \& Maxwell: London, 1920) at 15.

Indeed, it would be very uncommon for the statutory form of mortgage to reveal even the amount of the loan secured. Usually, reference is merely made to the governing loan documents which may or may not be registered in the appropriate provincial Company Registry. Whether or not the loan agreement is so registered will depend in part on whether or not the document contains assignments of insurances and charter hire from the drilling unit, in which case these assignments may well constitute assignments of book debts and therefore require registration of the loan agreement.

xs. In general, see William W. Spicer, Canadian Maritime Law and the Offshore: A Primer (The Canadian Institute of Resources Law, 1984).

ws. In Canada claims involving damage by a ship. salvage and seamen's wages give rise to maritime liens. These types of claims will also survive a change in ownership of a ship other than a change of ownership effected by a judicial sale ordered by the Federal Court of Canada. In that case, all claims against the ship are wiped out and the Court gives clean title to the purchaser. 
uncommon, however, for the general partner of a limited partnership to be the registered owner of a drilling unit.

\section{THE STATUS OF DRILLING CONTRACTS}

In maritime parlance, a drilling contract is most usually a time charter (i.e., a contract for the lease of a ship for a period of time). Because drilling units are ships, their leasing is necessarily effected by the use of a maritime contract. Such contracts carry with them various attributes peculiar to charter parties and which should be borne in mind when drafting a drilling contract:

1. The implied warranty of seaworthiness at the commencement of the contract. Such a warranty includes much more than the physical condition of the ship and extends to a requirement that the crew must be properly trained and instructed in the operation of the ship and its idiosyncrasies. ${ }^{88}$ This warranty may be avoided by appropriate language;

2. The "due diligence" obligation. Many drilling contracts contain provisions concerning the exercise of due diligence. ${ }^{89}$ This is well understood in maritime law as being the cornerstone of the shipowner's obligation. This obligation cannot be delegated. ${ }^{90}$ By way of example, the acquisition of certificates of seaworthiness and other statutorily required vessel certificates does not in and of itself constitute compliance with the requirement to exercise due diligence; ${ }^{91}$

3. Reduced hire rate provisions. Drilling contracts frequently contain provisions which provide for reduction of the hire rate. Such clauses in traditional maritime contracts are in the event of any doubt interpreted in favour of the owner by reason of the fact that such clauses are attempts to cut down the owner's right to hire, ${ }^{92}$ and

4. No right to set off hire. The owners' right to receive hire is absolute. A contractor would not be permitted to set off hire owing to the owner against some obligation flowing from the owner to the contractor in the absence of specific words so permitting.

See William Tetley, Maritime Cargo Claims 2nd. ed. (Toronto: Butterworths, 1978) at 157.

By the use of such inappropriate phrases as "good oilfield practice."

Maxine Footwear Co. Lid. v. Canadian Government Merchant Marine Ltd. , [1959] 2 Lloyd's Rep. 105 (P.C.) on appeal from the Supreme Court of Canada.

Charles Gondfellow Lumber Sales Ltd. v. Verreault, [1971] S.C.R. 522; Scottish Metropolitan Assurance Co. v. Canada Steamship Lines Ltd., [1930] S.C.R. 262. For a contrary view, see Norman v. Canadian National Railway Co. (the WILLIAM CARSON) (1982), 39 Nfld. \& P.E.I.R. 91.

Mareva Navigation Co. Lud. v. Canaria Armadora S.A. (The Mareva A.S.), [1977] 1 Lloyd's Rep. 368 at 381 . See also, Royal Greek Government v. The Minister of Transport, (1948) 82 Lloyd's Rep. 196 at 199. See also. Wilfred et al, Time Charters 3rd ed. (London: Lloyd's of London Press). 


\section{MARITIME TORTS AND LIMITATION OF LIABILITY}

One of the most significant benefits available to owners and operators of ships is the ability to claim limitation of liability in respect of a tort for which they are liable. ${ }^{93}$ Canadian law grants limitation where the event giving rise to the claim occurred without the actual fault or privity of the defendant owner/operator. Thus the owner may be tortiously liable in the sense that his employees were at fault but still able to claim limitation if the fault of the employees have not been contributed to by an officer or director of the defendant company..$^{94}$

If, for example, an accident is caused by high speed in fog, the limitation question is whether the officer of the company responsible for operations of the company's ships had in place an acceptable policy to ensure that the company's masters did not navigate at full speed in fog. ${ }^{95}$ If there is no such policy or its enforcement is haphazard, a Canadian court would in all likelihood find that the company was not entitled to limit liability. ${ }^{96}$ If the incident was caused by out of date charts, the court would be interested to know whether the company had a policy to ensure that charts were kept up to date, or whether it was just left to the master. In the latter case a claim for limitation would fail. ${ }^{97}$

Frequently, in deciding whether a shipowner's claim for entitlement to limitation will succeed, the courts are presented with evidence of the standards maintained by other competent shipowners. It is accepted that in order to successfully claim limitation the defendant owner's/operator's practices must not fall below those of good shipowners. The test is objective. In one famous case involving the Guiness Brewing Company, the Court of Appeal in England made specific note of the fact that the test was that of the reasonable shipowner. ${ }^{98}$ The Guiness Company had gotten into shipowning as a sideline to their major business of making beer, as a way to transport their own product. One of their ships, the LADY GWENDOLYN, proceeding at full speed in fog, collided with a vessel at anchor. Guiness admitted liability and claimed limitation. It was clear from the evidence that although Guiness made good beer they did not make good shipowners. In the Court of Appeal, Lord Justice Willmer commented:

Supra, note 73, ss 574-589. The effect of a successful claim for limitation is dramatic. In a claim not involving loss of life or personal injury, a successful claim for limitation of liability will render the total liability of the defendant owner or operator to an amount calculated on the basis of a ship's tonnage. The method for calculating the amount is set out in the sections of The Canada Shipping Act but at present it amounts to about $\$ 100$ per ton. In a case involving personal injury or death, it is about $\$ 300$ per ton. Indemnity claims made pursuant to contractual arrangements are not subject to limitation of liability (The Kirknes, [1957] P. 51). Grand Champion Tankers Lid. v. Norpipe A/S and Others (The Marion), [1984] A.C. 563 (H.L.). The Lady Gwendolyn, [1965] I Lloyds Rep. 335.

Canadian Courts have been very reluctant to grant limitation of liability. The obligation of the ship owner to prove he is entitled to limitation has been described by the Supreme Court of Canada in Stein v. The Ship Kathy K., [1976] 2 S.C.R. 802 by Mr. Justice Ritchie at 819 as "the burden resting on the ship owners is a heavy one." Canada is not a ship owning country and the possibility of an admittedly negligent ship owner being able to limit his liability for substantial damage caused by the negligence of his employees has been resisted by Canadian courts. 
Any company which embarks on the business of shipowning must accept the obligation to ensure efficient management of its ships if it is to enjoy the very considerable benefits conferred by the statutory right to limitation."

It is incumbent that drilling contractors with rigs working offshore ensure that the persons employed on the rigs are competent and that the company has an effective system in place to ensure proper management of the rigs. Failure to meet the test of the reasonable shipowner will, if the failure is any way causative of the loss, deprive the rig owner of the right to limitation. ${ }^{1(x)}$

\section{THE FISCAL REGIME}

Canada and the provincial governments of Newfoundland and Nova Scotia have paid considerable attention to the issues of which taxes will apply offshore and how they will be collected. The principal taxes and duties examined here are income tax, customs duties, goods and services tax and provincial sales tax.

\section{A. INCOME TAX}

Since the continental shelf is part of Canada for income tax purposes, a Canadian resident corporation or individual involved in offshore oil and gas activities will be treated exactly as if the continental shelf were part of Canada. Provincial income tax acts of both Newfoundland and Nova Scotia are also extended into their respective offshore areas pursuant to specific provisions in the Accord Implementation Acts.

For non-residents the following considerations apply:

\section{Carrying on Business in Canada}

Under the Income Tax Act, non-residents are liable for Canadian income tax on business profits earned in Canada if the non-resident has carried on business in Canada. ${ }^{101}$ Factors used in determining if a non-resident carries on business in Canada include:

(i) whether or not the non-resident solicits orders in Canada;

(ii) whether or not the contract is made in Canada for delivery of a product in Canada; and

(iii) whether or not operations from which the taxpayer's profits arise take place in Canada.

Broadly speaking then, many non-residents involved in continental shelf petroleum activities will be deemed to be carrying on business in Canada and, unless a tax convention gives relief, will be subject to Canadian income taxation. 


\section{Permanent Establishment}

Many tax conventions between Canada and other countries provide that so long as the non-resident's business profits in Canada, arising for instance from the sale and installation of equipment on a marine installation in the offshore, are not attributable to a permanent establishment in Canada, its business profits will be exempt from Canadian income tax. Some treaties like the U.K. - Canada Convention provide that a permanent establishment will include "a building site or construction or assembly project which exists for more than twelve months." ${ }^{102}$ Others, like the U.S. - Canada Convention, provide in addition to such a building site the "use of an installation or drilling rig or ship to explore for or exploit natural resources"103 ${ }^{103}$ for more than three months in any twelve month period. It will not be uncommon, therefore, to find that profits on a sale of equipment will not arise from a permanent establishment and will not attract Canadian income tax; on the other hand profits from the installation of that equipment and its maintenance may well exceed applicable time limits and may therefore be attributable to a permanent establishment in Canada and will be thus taxable in Canada.

It is important to allocate contract prices among the various components of goods and services provided.

\section{Shipping Profits}

Most treaties provide that profits from the operation of ships in international traffic to and from Canada will be taxable only in the state in which the taxpayer is resident. ${ }^{104}$

\section{Withholding - Contract Payments}

A production licensee must be a Canadian citizen or corporation ${ }^{105}$ and will be obliged to withhold fifteen percent of payments to non-residents in respect of services supplied in Canada. ${ }^{106}$ Services would include installation services, whether exempted by treaty or not, but not the sale of equipment. Non-residents exempted by treaty may apply for a waiver of the withholding requirements on the grounds that no tax liability will arise. Otherwise, they will have to wait until the end of the year and file for a refund.

The Canada-United Kingdom Income Tax Convention, brought into force December 17, 1980, Article $5(2)(g)$.

103. The Income Tax Convention hetween Canada and the United States, signed September 26, 1980. Article 5(4). 


\section{Withholding - Employees}

A non-resident must withhold from salary payments to its Canadian resident employees (and may have to withhold from salary payments to non-resident employees) a certain portion of that salary payment to be remitted to Revenue Canada in respect of income tax payable by that employee. ${ }^{107}$ Directors of the non-resident employer will be personally liable for amounts withheld from its employees and not remitted to Revenue Canada unless a defence of due diligence can be established. ${ }^{108}$

\section{B. CUSTOMS DUTIES}

Customs duties are chargeable on goods brought into Canada at rates based on the value of the goods. The rates vary depending on the classification of the goods. Contractors and others may wish to bring into Canada on a temporary basis goods such as drilling rigs or specialized installation vessels. If there is no duty paid equivalent equipment available for the task throughout Canada, customs authorities have the discretion to charge duty on an instalment basis, usually based on monthly payments of 1/120th each of the entire duty which would be payable if the goods were being permanently imported into Canada.

\section{GST}

As we are now all too familiar, the GST is a value added tax payable by the recipient of a taxable supply made in Canada. By a system of refundable tax credits to intermediate taxpayers in the production chain, the full burden of the GST is intended to be borne by the ultimate consumer of the goods or services. In offshore petroleum activities, there is almost no ultimate consumer use and the chief concern, therefore, is to examine whether the GST scheme works in accordance with this general intent when it is applied in the context of the continental shelf outside Canada, with resident and nonresident suppliers and resident and non-resident intermediate consumers.

Some of the key GST implications in the offshore context are the following: ${ }^{109}$

(a) Like the Income Tax Act (Canada), the Excise Tax Act extends "Canada" to include the continental shelf; ${ }^{110}$

(b) Some suppliers of goods or services must register under the GST. The chief advantage to registration is that only GST registrants can receive input tax credits.

\footnotetext{
107. Income Tax Act, supra, note 101 s.153(1).

Iox. Ibid. s.227.1(1) and (3).

11\%. The reader is asked to bear in mind that the degree of detail and accuracy necessary to be completely correct in any statement concerning the GST is beyond the scope of this paper and its authors gratefully acknowledge the assistance of Robert Arkin of McInnes Cooper \& Robertson in the preparation of this portion of the paper. 
Accordingly, it will be a benefit for intermediate purchasers of Canadian goods and services to register, if they can. The obligations of GST registrants are primarily to collect and remit GST to the federal government. And in some circumstances, liability to pay GST will depend upon whether the vendor is registered. The disadvantages and advantages to registration must be weighed in each instance by that small group of businesses who may, but are not required to, register;

(c) GST registration rules are these;

(i) a Canadian resident making taxable supplies of goods or services must register;

(ii) a non-resident who maintains a permanent establishment (using a definition similar to that used in most international tax treaties) is deemed to be a Canadian resident in respect of activities carried on through that establishment, and must therefore register;

(iii) a non-resident without a permanent establishment but who carries on business in Canada must register. This determination will normally be based on whether or not contracts are regularly completed in Canada and whether or not profits substantially and regularly arise from Canadian activities; and

(iv) a non-resident who does not have a permanent Canadian establishment and does not carry on business in Canada but who does carry on infrequent commercial activities in Canada or who regularly solicits orders in Canada may, but is not required to, register; and

(d) GST liability rules include these:

(i) a supply made by a non-resident, non-registered person is generally deemed to have been made outside Canada, therefore no GST is payable;

(ii) a supply of tangible personal property made by a non-resident registered person will be deemed to have been made in Canada if the goods are delivered to the recipient in Canada, in which case GST is payable;

(iii) a supply of services performed by a non-resident registered person will be deemed to have been made in Canada if the service is performed in whole or in part in Canada, in which case GST is payable; and

(iv) a supply of goods made entirely outside Canada by a non-resident (registered or not) may not attract GST, but if the recipient subsequently imports the goods into Canada, an importation tax equal to the GST will be payable. 
A typical transaction in which these rules would apply would be that a production licensee has contracted with a foreign company to manufacture, outside Canada, a major component of an offshore production platform, to ship it to an eastern Canadian port for certain final modifications by a local firm and then to install it on the platform on the continental shelf. Property would not pass to the licensee until the component is installed.

GST will be payable on the modification work. If the installation work is the only work conducted by the foreign company in Canada, it will likely not constitute carrying on business in Canada so that the foreign company will not be required to register. It will likely constitute carrying on a commercial activity so that the foreign company will be eligible to register for the GST; the right to register will be strengthened, and even perhaps be turned into an obligation, if the foreign company completes its contract with the production licensee in Canada.

If the foreign company does register, both the supply of the component and its installation will attract GST. The foreign company will collect the GST and remit it to the federal government. The foreign company will get a refund of the amount it paid for the modifications.

If the foreign company chooses not to register there will be no GST payable by the production licensee in respect of either the supply of the component or the installation of the component. The drawback will be that the foreign company will have to pay GST on the modifications and will not be eligible for any offsetting input tax credit. A solution in this instance might be to have the production licensee contract for the modifications.

In summary, except for ultimate consumer uses of goods and services, the GST collection system is designed to match tax liability with input tax credits. Since continental shelf hydrocarbon activities will involve almost none of such consumer use, the chief GST issues involve testing the concept of GST transparency through the complex interacting rules on residency, non-residency and deemed residency; mandatory, permitted and prohibited registration; permanent establishment, carrying on business and conducting commercial activity; intra-Canadian and extra-Canadian supplies of goods and services.

\section{PROVINCIAL SALES TAX}

Both Accord Implementation Acts provide for the application of provincial sales tax legislation in the offshore.

In Newfoundland, the Retail Sales Act provides, through a recent amendment, for a four percent sales tax on the purchase of goods to be used in the Newfoundland offshore. In some cases the tax is nil.

In the Nova Scotia offshore, the governments are charging and collecting a sales tax of four percent of the purchase price of tangible personal property consumed or used in 
the production or processing of non-renewable resources." Non-Renewable Resources Production or Processing Health Services Tax Regulations, ${ }^{112}$ machinery and apparatus used for the purpose of extraction of petroleum at petroleum extraction sites is deemed to be engaged in the production or processing of non-renewable resources. If the tangible personal property is not so engaged, the general sales tax rate of ten percent will normally apply. The purchase price includes transportation costs, GST and customs duties. Finally, instalment payments on goods brought temporarily into the offshore, generally on the same basis as the Customs duties instalments, are permitted.

\section{ENVIRONMENTAL REGULATION}

Just as onshore, diverse legislation from different points of view effect all phases of offshore oil and gas activities - from initial exploration to shipment of produced substances.

\section{A. EXPLORATION}

All exploration, development and production phases are governed from a technical point of view by the Accord Implementation Acts. Both Acts remove the application of the Oil and Gas Production and Conservation Act ${ }^{113}$ from their respective offshore areas but contain provisions almost identical to that act for technical compliance. Broad regulation making power is conferred in relation to, for instance:

(i) the safety and inspection of all exploration, drilling, production, conservation, processing and transportation of petroleum;

(ii) preventing waste;

(iii) setting conditions under which drilling operations may be carried out;

(iv) prescribing measures necessary to prevent pollution of air, land and water as a result of exploration, drilling, production, storage, transportation and processing of petroleum; and

(v) approvals and requirements applicable to work authorizations.

The Chief Conservation Officer ${ }^{14}$ is charged with the administration of technical compliance in each offshore area.

Under the Accord Implementation Acts, unauthorized discharges, emissions and escapes of petroleum ("spills") are prohibited. ${ }^{115}$ Spills must be reported to the Chief "It his Act shall not apply in the offshore area ...." This has not slowed the government's revenue gathering enthusiasm.

R.S.C., 1985, c.0-7.

Newfoumdland Accord Act, s.140; Nova Scotia Accord Act, s.144.

Newfoumdland Accord Act, s.161(1); Nova Scotia Accord Act, s.166(1). 
Conservation Officer who will have broad emergency powers including taking over the management of the project to contain and clean up any spills. ${ }^{116}$

The holder of the exploration, significant discovery or production license will be strictly liable up to prescribed limits for actual loss and damage sustained by third parties as a result of either authorized or unauthorized spills. ${ }^{117}$ The prescribed limit in Newfoundland is $\$ 30,000,000$ and while no regulation has been made in Nova Scotia, that same amount is intended to be prescribed.

In addition to these provisions of the Accord Implementation Acts, exploration activities will be subject to the following.

\section{B. SECTION 67(1) OF THE CANADA ENVIRONMENTAL PROTECTION ACT (CEPA) 118}

Part VI of CEPA replaces the Ocean Dumping Control Act and prohibits the unauthorized dumping of any substance in, among other areas, the continental shelf from any ship, aircraft, platform or other anthropogenic structure. By s. 122 of CEPA, directors, officers and agents of a corporation who authorized or acquiesced in the commission of an offense under s. 67(1) are also guilty and liable to either a fine or imprisonment or both for that offence. A due diligence defence to such personal liability is provided for in s. 25 .

\section{SECTIONS 35 AND 36 OF THE FISHERIES ACT ${ }^{119}$}

Under these provisions it is an offense to carry on any undertaking which results in the harmful alteration, disruption or destruction of a fish habitant, or to deposit or cause or permit any unauthorized deposit of material deleterious to fish in water frequented by fish.

\section{TRANSPORTATION OF DANGEROUS GOODS ACT ${ }^{120}$}

This Act contains an array of offenses relating to the manner in which dangerous goods may and may not be carried in all Canadian offshore areas. This Act requires the use of prescribed equipment, special authorizations and warnings and specially trained drivers. The spills must be reported and cleaned up. Section 11 imposes personal liability on directors and officers of offenders, though, again, a defence of due diligence is provided.

\footnotetext{
116. Newfoundland Accord Act, ss.161(2)-(5); Nova Scotia Accord Act, s.166(2)-(5).

117. Newfoundland Accord Act, s.162(1)(a); Nova Scotia Accord Act, s.167(1)(a).

IIx. S.C. 1988, c.22.

119. R.S.C. 1985 , c. F-14.

i2*. R.S.C. 1985 , c. T. 19 .
} 


\section{E. DEVELOPMENT}

All the environmental legislation applicable to exploration activities also applies to development activities. In addition, environmental assessment legislation applies to the start up of and planning for production facilities.

Until s. 7 of the Canada Law's Offshore Application Act is proclaimed, the main body of provincial law, including provincial environmental assessment legislation, will not be applicable anywhere on the continental shelf. In the federal realm, the Canada Environmental Assessmem Act has not been passed and therefore, by default, the applicable environmental assessment legislation is the 1984 Environmental Assessment and Review Process Guidelines Order, ${ }^{121}$ (the "Guidelines Order"), which has been the subject of much recent litigation. ${ }^{122}$

The applicability of the Guidelines Order to a specific project requires some triggering event of federal involvement, ${ }^{123}$ for instance:

(a) the approval of the Canadian ownership content of the production licensee by the federal Minister of Energy Mines and Resources; ${ }^{124}$

(b) the approval of the federal Minister of Fisheries under s. 35(2) of the Fisheries Act to disrupt a fish habitat; ${ }^{125}$ and

(c) the approval of the Minister of Transportation to construct and maintain workings in navigable waters. ${ }^{126}$

Any project requiring any one of these approvals is subject to the Guidelines Order.

The Guidelines Order requires the selection of an initiating federal department among those whose approvals are required and the initiating department then conducts an initial review coordinating the concerns of every other involved department. Depending upon the outcome of that review, the Minister of the initiating department may be required to refer the project to the Minister of the Environment for public review by a panel of independent, politically unbiased and technically knowledgable members.

In the early rounds of Guidelines Order litigation, the federal government claimed that the Guidelines Order did not apply, or that they could ignore its application if they wanted

SOR/84-467.

Sec, for example, Friends of the Oldman River Society v. Minister of Transport et al. (1990), 5 C.E.L.R. (N.S.) I (F.C.A.D.); Saskatchewan Water Corporation v. Canadian Wildlife Federation Inc. et al (1989), 4 C.E. L.R. (N.S.) 1 (F.C.A.D.), approving 3 C.E.L.R. (N.S.) 287 (F.C.T.D.); Cantwell et al v. Minister of the Emiromment et al., an unreported decision of Mackay J., (F.C.T.D.) No. T2975-90 rendered January 18, 1991 (Pt. Aconi).

Supra, note 113, s.6.

Newfoumdland Accord Act, s.89: Nova Scotia Accord Act, s.91.

R.S.C. 1985, c.F-14.

Navigable Waters Protection Act, R.S.C. 1985, N-22, s.5(1). 
to or that prior provincial assessment made federal assessment unnecessary and discretionary. The courts soundly rejected all such arguments and the more recent litigation has centred around whether the efforts of compliance of the initiating department have indeed satisfied the requirements of the Guidelines Order.

When the courts have found that the federal government did not comply with its own Guidelines Order, the remedy has been to quash the federal government approval or consent. The party most adversely affected by such a decision is, of course, the proponent of the project and for this reason it is submitted that the proponent cannot blindly rely on a federal governmental approval, but must instead work with the federal government and take whatever steps it can to help insure that the initiating department cuts no corner, considers all relevant information and bases its conclusions on relevant reliable non-political evidence.

Another form of environmental assessment of a project is provided for in the Accord Implementation Acts. Before production activities may commence, a production licensee must obtain from the Offshore Board an operating license together with certain work authorizations and approvals. ${ }^{127}$ No such approval may be granted without the consent of both federal and provincial energy ministers, unless the Board has approved a development plan for the project. ${ }^{128}$ One of the topics of any development plan is the "costs and environmental factors in connection with the proposed development" ${ }^{129}$ and in general the development plan must provide all information necessary for a comprehensive review and evaluation of all aspects of the project. ${ }^{130}$

The licensee's development plan, combined with the broad powers of the Board to initiate comprehensive public reviews, may result in a process that may imitate a Guidelines Order review.

It is submitted, however, that the courts have interpreted the Guidelines Order as a very special piece of legislation; similar review processes may not have the same prominence, especially where the political independence of the members of any public review panel is not carefully provided for. Proponents of offshore projects must carefully evaluate all aspects of any environmental assessment process said to replace the application of the Guidelines Order and determine for themselves whether the adoption of such alternate process will leave any federal approval or other involvement in the project open to attack.

\section{F. PRODUCTION}

By the time production commences, all environmental assessment questions will have been resolved. All the provisions applicable to exploration activities will apply in the production stage. In addition, the following legislation affecting the handling of produced oil or gas will apply. 


\section{G. CANADA SHIPPING ACT}

Part XV of the Canada Shipping Act prohibits spills in the same manner as the Accord Implementation Acts, but specifically does not cover spills covered by the Accord Implementation Acts. Accordingly, spills from ships (including drilling rigs) resulting from exploration or drilling for or production or processing of oil or gas are exempt from the Canada Shipping Act, but caught by the Accord Implementation Acts. The Canada Shipping Act prohibits spills of oil held on board as cargo or as fuel. It concerns, therefore, such potential disasters as tanker spills. As with other maritime liabilities discussed above, ${ }^{131}$ limitation of the ship owner's liability is available where the incident occurs without the actual fault or privity of the owners. ${ }^{132}$

\section{H. ACCORD IMPLEMENTATION ACTS}

The Accord Implementation Acts prohibit "waste" as understood in the oil and gas industry to include dissipation of reservoir energy, operations likely to cause unnecessary loss of produced petroleum, flare and gas which could be recovered and used or reinjected in the reservoir, etc. These Acts also give a civil remedy to any person who incurs actual loss or damage from an improperly abandoned installation or structurc. This remedy is against the holder of the production license at the time the installation or structure was used and, again, liability does not require proof by the injured party of fault or negligence.

\section{CONCLUSION}

This brief summary attempts to show that the legislative management of offshore petroleum rights and operations is far different from the regime in place in the early 1980's. The international basis for legislative and ownership rights is still the same UNCLOS III. The constitutional division of legislative powers within Canada, however, has been for the most part judicially and political settled. New legislation geared more to regulating the industry than to altering the constitutional balance of powers has been proclaimed in force by both federal and provincial governments. Many of the powers of the federal Minister of Energy Mines and Resources have been passed over to the Offshore Boards.

Under the Accord Implementation Acts, much of the provincial laxing schemes and social legislation have been extended to oil and gas operations on the continental shelf. In addition, the personal property security laws of Newfoundland have been extended to the continental shelf.

Federal laws have been comprehensively extended to offshore marine installations under the Canadian Laws Offshore Application Act. The section of this Act similarly extending provincial laws awaits proclamation. 
We thus know, as we did not know previously, what laws are in force and what laws apply. This basic certainty is comforting and the legal challenges now facing us are the coordination of the various pieces of legislation and the interpretation of particular provisions. We have identified the particularly interesting areas of priority of registered rights versus statutory liens against an exploration, significant discovery or production license; the sorting out with greater precision of the application and jurisdiction of different union certification and other social legislation statutes, the breadth of the Workers Compensation Act bar to separate action against an employer and the development of a smooth environmental assessment policy have also been addressed. 